\title{
Business cartels and organised crime: exclusive and inclusive systems of collusion
}

\author{
J. D. Jaspers ${ }^{1}$
}

Published online: 15 September 2018

(C) The Author(s) 2018

\begin{abstract}
In this article, two case studies of large-scale bid rigging in the construction industry in Canada and the Netherlands are analysed to explore why business cartels sometimes do and sometimes do not involve organised crime. By combining concepts from both organised crime and organisational crime, an integrated understanding of the organisation of serious crimes for gain is applied. Across time and space, businesses in the construction industry are known to fix prices, use collusive tendering and divide market shares in illegal cartel agreements. In order to stabilise cartels, participants need to ward off new competitors and prevent cheating within the cartel. The question why we see a system of collusion involving organised crime and violence in Canada as opposed to the Netherlands is answered through analysing two comparable cases. This article finds two systems of bid rigging emerge under different cultural conditions: inclusive and exclusive collusion. The exclusive system makes use of the violent reputation provided by criminal groups and distinguishes from the inclusive system that uses sophisticated administration of mutual claims in shadow bookkeeping.
\end{abstract}

Keywords Business cartels · Bid rigging · Construction industry · Organised crime · Corporate and white-collar crime

\section{Introduction}

When firms in the same market control competition between them by fixing prices, sharing markets or rigging tendering procedures they engage in a business cartel (Harding and Joshua 2010). Firms involved in business cartels need to conceal their illegal conduct from customers, non-participants and internal and external watchdogs (Baker and Faulkner 1993). However, besides keeping enforcement and other

J. D. Jaspers

jaspers@law.eur.nl

1 Erasmus School of Law, Department of Criminology, Erasmus University Rotterdam, Burgemeester Oudlaan 50, 3000 DRRotterdam, The Netherlands 
watchdogs in the dark, participants also have to ensure that other firms in the cartel comply with the illegal agreements. Cartelists monitor prices, customers, and tendering procedures and negotiate compensations to ensure compliance with cartel agreements (Faulkner et al. 2003). In addition to communication and negotiation (Jaspers 2017), some cartels use - the threat of - price wars or exclusion from the market to deter or sanction cheaters within the cartel (Ayres 1987; Connor 2010; Levenstein and Suslow 2006; Bhaskarabhatla et al. 2016). In other cases, potential instability within cartels is prevented using the protection of organised criminal groups and the (threat of) violence (Varese 2014).

In the latter category of cases, organised criminal groups - organisations or networks established with the aim of executing criminal activities (van de Bunt and Huisman 2004) - supposedly act as 'cartel enforcers'. Both by controlling compliance of firms to the existing agreements in the cartel and by preventing outsiders of the cartel from entering the market they enforce the existing cartel. Involvement of criminals with a violent reputation can solve issues regarding internal instability of the cartel (Gambetta and Reuter 1995). Through extortion or persuasion, organised criminals offer 'protection' services in exchange for commission or 'pizzo' from the derived profits of cartels (Varese 2014, p. 345). The literature on organised crime extensively discusses examples of the involvement of organised criminal groups in economic cartels (Varese 2014; Stephan 2010; Chu 2002; Gambetta and Reuter 1995; Reuter 1983). The studies that specifically deal with cartels generally label these examples of involvement as 'infiltration' of organised crime in legitimate business sectors. These cases entail involvement of the Cosa Nostra in the construction industry in New York (Jacobs et al. 1999; Jacobs 1991, p.49) and in the food-, clothing- and transportation industry in New York (Mass 1991, p. 37; Reuter 1987, 1985); involvement of mafia in the fruit- and vegetables wholesale (Gambetta and Reuter 1995) and in the construction industry in Sicily (Gambetta and Reuter 1995); the flower cartel in Sicily (Varese 2011a, b, p. 102; Franchetti 1876); criminal groups in the taxi industry in South Africa (Stephan 2010, p. 353); and protection against competition by the Triads in Hong Kong (Chu 2002, p. 77-80). However, contemporary literature on organised crime takes a more nuanced approach concerning the interactions between 'licit' and 'illicit' services and 'formal' and 'informal' economies (Passas 2002; van Duyne 1995, 1996). These studies emphasize the overlap and symbiosis between corporate and criminal actors, or 'upper' and 'underworld' (van de Bunt et al. 2014; Lippens \& Ponsaers 2006; Ruggiero 1997).

In addition, not all business cartel agreements involve organised crime. In the literature on corporate and white-collar crime, business cartels have also received ample attention. These cases entail, for example, the ADM lysine cartel in the US (Conley \& O'Barr); the heavy electrical equipment cartel cases in the US (Geis 1987); and pricefixing in the pharmaceutical industry (Braithwaite 1984). Geis (1987) already pointed to business cartels as a severe form of corporate crime in his seminal study on pricefixing. Additional studies throughout the years have underlined how anti-trust and competition violations are both the most persistent and most profitable form of corporate crime (Clinard and Yeager 1980; Shapiro 1984; Braithwaite 1989; Jamieson 1994). White-collar crime studies on business cartels mostly explain cartel agreements by the need of corporate actors to minimise risks and manage uncertainties (Agnew et al. 2009; Jamieson 1994; Geis 1987; Parker 2013; Piquero 2012; 
Sonnenfeld and Lawrence 1978). However, these studies do not discuss cartels that involve criminal groups and networks. Thus, the literatures on organised and organisational crime offer separate and different accounts of a similar phenomenon.

This paper attempts to take into account insight from both (sub) fields of criminological study to explain why business cartel agreements sometimes do and sometimes do not include the involvement of organised criminal groups. van Duyne (2007) already noted the obvious interconnections between business cartels and organised crime. For example, business cartels fit all the criteria for the UN and EU definitions of organised crime, except for criminal prosecution in the Netherlands. Ruggiero (1996) also discusses the analytical similarities between white-collar crime (Sutherland 1949) and organised crime and suggests a joint analysis based on the theory of organisations and the theory of the firm. Moreover, Dorn (2009) suggests that organised crime as a concept is becoming redundant in favour of 'serious crime' in both policy and research. In synthesising the research traditions of organised crime and organisational crime, scholars have suggested working towards theorising the organisation of 'serious crimes' (Edwards and Levi 2008) and 'serious crimes for gain' Lord et al. (2017). Moving away from conceptual debates on the differences between organised and organisational crime we can focus attention towards understanding how networks of perpetrators and facilitators are formed around serious crimes for gain; what resources they use, how they operate and how they are developed and maintained throughout space and time. Cartels can be considered as such a form of serious crime for gain. Cartel crimes can involve non-violent modus operandi; sophisticated schemes, market associations, informal meetings, shadow book keepings, as well as violent modus operandi; violence and the threat of violence.

This raises questions regarding the nature and causes of the involvement of organised criminal groups in business cartels. Why is it that we sometimes do and sometimes do not see involvement of organised crime and the use of their violent reputation in business cartels? What explains the differences between violent and nonviolent business cartels? To examine these issues, bid rigging in the construction industry is analysed in both the Canadian province of Quebec (cf. ReevesLatour and Morselli 2016; Hudon and Garzón 2016) and the Netherlands (cf. Van den Heuvel 2005; van Duyne 2007; Van de Bunt 2010; Hertogh 2010). In both cases, large-scale bid rigging in several markets of the construction industry lasted decades and both cases were investigated through extensive parliamentary inquiries. In this article, the publically available records of the investigations from $L a$ Commission sur l'octroi et la gestion des contrats publics dans l'industrie de la construction (CEIC 2015) and Parlementaire Enquetecommissie Bouwnijverheid (PEB 2002) will serve as data for a comparative analysis. Using these types of secondary sources has proven a useful and successful approach (cf. Clinard and Yeager 1980; Della Porta and Vannucci 1999; Van den Heuvel 2005; Van de Bunt 2010; Hudon and Garzón 2016). The design for making this comparative analysis is based on the Most Similar Systems Design, commonly used in comparative politics (cf. Anckar 2008). Many of the characteristics of the two case studies, such as organisation and culture of the industry, economic and market parameters are similar. However, despite the similarities, one significant difference is that in Quebec, violent modus operandi by organised criminal groups were used in some of the cartels. In the Netherlands, no such modus operandi were used. 


\section{Theory: From protection to collaboration}

\section{Government replacement and protection theory}

An influential explanation for the involvement of organised crime in several sectors of the economy is the idea of government replacement or protection theory (Anechiarico 1991; Della Porta and Vannucci 2012; Hill 2014; Gambetta 1993; Gambetta and Reuter 1995). According to this theory, the role of organised criminals would be the result of governments failing to provide certain protection to corporations or individuals (Hill 2014; Gambetta 1993). Instead, organised criminals provide these services and guarantees. Concerning the involvement of organised crime in business cartels, Gambetta and Reuter (1995) explain: "The state is unable to or unwilling to meet the demand of entrepreneurs for profit-enhancing and risk-reducing regulation; the mafia provides the service instead" (p. 132). Della Porta and Vannucci (2012) also connect the involvement of organised crime with a lack of effective government regulation; organised crime replaces an absent government. Several authors use the perspective of government replacement to study different cases of organized crime in several (national) contexts and formulated the idea of protection theory (cf. Kleemans 2014; Shortland and Varese 2014; Paoli 2003). Protection theory searches for analytical links between the absence of state-involvement and the emergence and behaviour of criminal groups. For instance, explaining violence as a means to protect stolen or illegal assets or to ensure criminal agreements in general (Campana and Varese 2013).

Several scholars also criticize protection theory (Paoli 2002, 2003; Kleemans 2014). Although Paoli (2002, 2003) recognizes that mafia type organisations can provide protection and potentially replace certain political functions, she points out that those groups are not exclusively involved in organised criminal activities. Flexible, multifunctional organisations and criminal networks - that do not resemble the hierarchical structure of mafia type organisations (2002) - perform many activities that qualify as organised crime (e.g. participating in illegal markets). While so-called protection to businesses may be a service traditionally provided by hierarchical criminal organisations, flexible criminal networks may not be involved in providing such services. Therefore, the type of organised crime present in a particular area might influence the likelihood of involvement of organised crime in business sectors. Additionally, Kleemans (2014) points out how protection theory lacks a good notion of the analogy between organised criminal groups and states: "states neither guarantee illegal transactions in illegal markets nor illegal operations in legal markets (p. 37)". In other words, protection theory does not explain those activities, which are deliberately not protected by states, because of moral objections or its harmful effects. Also, government replacement and protection theory insufficiently explains the involvement of organised crime in states that do have strong public protection. The fact that organised crime also occurs in countries generally considered as 'strong states', empirically underlines this argument (Fijnaut 1998; Kleemans and Van De Bunt 1999; Kleemans and Van de Bunt 2003). This translates to the topic of cartels, as even in a strong state with a powerful economy like the Netherlands businesses have proved to be able to effectively establish and maintain business cartels (cf. Van den Heuvel 2005; Van de Bunt 2010; Hertogh 2010). 
Three implications from the literature on organised crime relevant to business cartels are: 1) protection theory might insufficiently explain certain activities considered as organised crime, because involvement of organised crime in business cartels may not be the result of an absent government; 2) some types of organised crime are not involved in protection services; 3) and the distinction between hierarchical and flexible organised criminal groups might therefore have implications for the involvement of organised crime in business cartels.

\section{White-collar crime as organised crime}

Sutherland (1949, p. 228) already noted how white-collar crime relies on the corporate form of organisation and should therefore be considered organised crime. Building on this, Ruggiero (1996) purposes a joint analysis using organisational theory for the often conceptually distinguished phenomena of white-collar and organised crimes. Social networks around serious crimes for gain are known to involve interactions between 'licit' and 'illicit' services and 'formal' and 'informal' economies (Passas 2002; van de Bunt et al. 2014; Lippens \& Ponsaers 2006; Ruggiero 1997; van Duyne 1995, 1996). Different types of relationships between organised crime and legitimate business, or upper- and underworld are distinguished (van Duyne et al. 2002). Passas (2002) developed a theoretical framework in which he categorises relationships as antithetical or symbiotic. Firstly, antithetical relationships refer to a form of competition between legal and illegal actors, a predatory nature of the relationship and unequal power balance between actors. For example, in a parasitical relationship criminal groups use business actors to extort illegal profits on a regular basis. In this situation, businesses are seen as victims of extortion (cf. Varese 2014). Secondly, symbiotic relationships between legal and illegal actors revolve around supply and demand for network and services, mutual benefits and an equal balance of power. For example, in collaboration actors work together towards executing the offence and are both willing participants (cf. Gambetta 1993; Gambetta and Reuter 1995). Besides collaboration, parties can be involved in a relationship defined as cooptation; there are still mutual benefits to the collaboration but an uneven power balance between them (Passas 2002).

These studies demonstrate how different actors may participate for their own personal or organisational goals and motivations, benefiting from specific collaborations. Hence, to understand the involvement of organised crime in business cartels, one must appreciate the nuanced nature of the motives and interactions of illegal and legal actors. This requires considering firms and corporate personnel as more than just willing or vulnerable victims of extortion and forced upon influence by organised criminal groups. Because, the risk of a one-dimensional approach is that you might frame an economic crime problem as an organised crime problem or vice versa, by overstating the influence or power of certain actors (Morselli et al. 2012).

\section{Methodology: Data sources and analysis}

For the purpose of this article, the publically available records of the investigations from La Commission sur l'octroi et la gestion des contrats publics dans l'industrie de 
la construction (CEIC 2015) and Parlementaire Enquetecommissie Bouwnijverheid (PEB 2002) served as data for a comparative analysis. These publically available reports contained: transcripts from witness testimonies, police evidence including wiretaps and video surveillance, demographic information, economic and market studies. A document analyses was performed on these sources based on a topic list including the following topics: general case information, type of actors, structure of the industry, market indicators and the modus operandi of the cartels. In addition, information on regulatory regimes and regulatory changes during the active years of the cartels was gathered and analysed.

\section{Comparing cases: Similar circumstances, different outcomes}

\section{Regulatory changes}

\section{Canada}

Canada has a long-standing history of criminalising cartel conduct, dating back to 1892, when Canada's competition legislation was incorporated into the criminal code (Boscariol et al. 2010). However, antitrust law did come under fire of the provinces in the 1930s. Up to the year 1976 there were only criminal provisions against unfair competition in Canada, after 1976 civil provisions were added to this. In 1986, the current competition act was passed In Canada, partly decriminalising competition law. Although cartels remained subject to criminal sanctions, new non-criminal provisions were drafted for merger reviews and abuse of dominance. In 2010, amendments were made in the Canadian Competition Act. The cartel prohibition came into force with the introduction of a per se criminal offence for certain 'hard-core' cartel behaviour (Boscariol et al. 2010). In terms of regulatory practices, the biggest changes were made from 2011 onwards, in the form of an institutional rearrangement of the anticorruption environment. Both a new Anti-Corruption Act and Quebec's Permanent AntiCorruption Unit were instated. The permanent coordination unit incorporates within the same structure, two construction regulatory agencies, police squads from municipal and provincial levels, a panel of public prospectors, and special teams from Quebec's Revenue Agency and Quebec's Ministry of Municipal Affairs and Land Occupancy (Reeves-Latour and Morselli 2017). The construction industry was pressured heavily by the creation of these new agencies and increased regulatory scrutiny (Reeves-Latour and Morselli 2017).

\section{The Netherlands}

Organisational structures in the construction industry in the Netherlands were in place since the early 1950's; industry associations and clubs enabled and ensured 'regulation of competition' in the industry. For example, the roads and construction combination 'WAC', that was founded in 1953 and the 'SPO', an overarching organisation regulating the pricing in the whole construction industry, which represented 28 cartels with more than 4000 firms involved and was founded in 1963 (Dohmen and Verlaan 2004). Dutch government approved these associations. At this point, there was no active 
enforcement against cartel conduct in the Netherlands, just a few officers in the Ministry of Economic Affairs dealt with the most excessive market power cases. They were provided with very little resources; hence, their activities were limited. In addition, there was no explicit cartel prohibition under Dutch law. There was the code on Economic Competition (WEM). However, this merely provided a provision that prohibited abuse of a cartel or market dominance, classifying as a criminal offense. In addition, there was a legal provision in the Dutch criminal code, but both the provision in the code on Economic Competition (WEM) and in the criminal code were hardly used in practice (de Bree 2006). This meant a tolerant enforcement climate for cartels in the Netherlands, and during roughly 40 years, there was no active enforcement of cartels in the Netherlands. Indeed, since 1962 there was a cartel register at the ministry of Economic affairs. Businesses could get their cartel legally registered, to ensure government approved them (cf. Petit 2017, p. 41-42). The rationale behind the register was that it enabled the Ministry to monitor that firms would not abuse cartels. However, calculated estimates demonstrated that only about half of active cartels were registered during that time (de Jong 1990).

Meantime, the institutions of the European Union aimed to promote one internal European market and as a means to that end wanted to decrease national cartels in its member states. They applied political pressure and introduced new legislation against unfair competition. Also in the Netherlands, a gradual regulatory shift was starting to take place regarding legislation and enforcement of unfair competition. Finally, the Dutch price regulating association for the construction industry 'SPO' was prohibited and abolished by a 1992 decision from the European Commission (PEB 2002, p. 87). This meant that many common practices in the construction industry, such as the preconsultation agreements in tendering procedures and collective price-regulation, were no longer allowed in the sector. In practice however, most negotiations and priceregulation practices continued 'underground', in secrecy. In 1998, the Dutch government eventually introduced new and stricter legislation in which all cartels, in an effort to end the so-called 'cartel paradise', were explicitly forbidden for the first time. This meant that all efforts by corporations to hinder fair competition, such as bid rigging, price-fixing and market allocation, were explicitly forbidden under administrative law. Note, formally decriminalisation took place, bringing anti-cartel legislation from criminal into administrative law. However, from that moment onwards corporations and their officials could be punished by far more severe financial penalties than ever before. Administrative fines up to $10 \%$ of the annual turnover of the company or personal fines up to 500,000 Euros were introduced. In 2016, this was increased to a maximum of $10 \%$ annual turnover of 4 consecutive years, or 900,000 Euros in personal fines. ${ }^{1}$ Moreover, the certainty of punishment increased. With the introduction of the cartel prohibition in Dutch law a new independent regulator was installed in 1998 by the Ministry of Economic affairs, namely the Dutch Competition Authority (now: Netherlands Authority for Consumers and Markets). This authority was provided with resources and investigative powers and this is seen as the starting point of competition law enforcement in the Netherlands.

${ }^{1}$ Stb. 2016, 22. 


\section{Economic and market conditions}

\section{Canada}

Since 1996, there was an increase in overall employment in the construction industry in Canada of $90 \%$, with 11,000-16,000 jobs annually. The sector of civil engineering and roads had two specific periods of growth, namely between 2002 and 2004 and between 2008 and 2012. Between 1996 and 2012, investments in this industry went up from roughly 4 to 17 billion CAD. The main client in this market is the government, which awards public contracts to construction companies (CEIC, Tome1 p. 76-96). In 2002, the department of Public Contracts of Montréal calculated that the costs of public contracts were 30-35\% higher than Toronto or Quebec City (CEIC, Tome 2 p. 9). In 2014, there were 2683 companies working in the civil engineering sector in the province of Quebec, of which 1109 companies in the Greater Montréal area. The majority $(83 \%)$ of construction firms in Quebec employ five or fewer employees. However, they account for only $19 \%$ of the income, which indicates high degree of concentration in the industry (i.e. a few large companies taking up a majority of the total market). In fact, 20 companies have a workforce of between 201 and 500 employees, and two employ more than 500 employees. In addition, the commission pointed out that the use of consortia and joint ventures is very common in the construction industry of Quebec (CEIC, Tome 1, p. 90).

\section{The Netherlands}

Between 1998 and 2000, the Dutch construction industry had an economic boost. In $2001,446,000$ people were working in the construction industry, accounting for more than $7 \%$ of total national Dutch employment. There were 65,000 construction companies at that time, of which roughly $75 \%$ was considered very small with no employees (individual freelancers), $90 \%$ had less than 10 employees and 10\% had 10-100 employees (PEB 2002, p. 56). For the purpose of the comparison in this article, we will focus on the civil engineering and infrastructure sector (e.g. sewing, roads, tunnels etc.). This sector was relatively concentrated compared to other sub-sectors in the Netherlands; 21 large firms (with more than 500 employees) held a combined total market share of $60 \%$. In 2002, the sector had an annual turnover of 15 billion Euros. The main client in this sector is the government, accounting for more than 5 billion Euros in 2002 (PEB, p. 56; van de Bunt 2008). In addition, it is common for companies to work together in the industry using subcontracting, combination works and outsourcing of excess work or activities in which they have little experience. Ergo, there is a high degree of cooperation between firms in this sector. For example, in the asphalt industry, 8 companies together divided $70 \%$ of the projects in and around Schiphol (PEB 2003, p. 557; van de Bunt 2008, p. 135). The parliamentary commission pointed out that although the economic conditions facilitated large-scale bid rigging to occur, these circumstances can be seen as a conditio sine qua non; only in combination with a specific business culture could they evolve into large-scale irregularities in the Dutch construction industry. A combination of tradition and business culture made construction firms continue to coordinate bidding and regulate pricing, after this conduct was explicitly forbidden (PEB 2002, p. 51) (Table 1). 
Table 1 National statistics construction industry Canada and the Netherlands

\begin{tabular}{lcc}
\hline & Canada & The Netherlands \\
\hline Population & 35.6 million people & 16.8 million people \\
Employment & 255,600 people in 2014 & 446,000 people in 2001 \\
construction industry & $(6.3 \%$ total employment $)$ & $(7 \%$ total employment $)$ \\
Number of companies & 350,000 in 2014 & 65,000 in 2001 \\
in construction & (Quebec: 2683, Montréal: 1109$)$ & \\
Annual turnover & 17 billion CAD in 2012 & 15 billion EUR in 2002 \\
& (6 billion public tenders) & (5 billion in public tenders) \\
\hline
\end{tabular}

Several parallels can be drawn between Canada and the Netherlands, both in terms of the structure and nature of the construction industry and in terms of the legislative and political context. However, a notable difference is the level of concentration and number of construction firms in the local market. High concentration in the Quebec market (i.e. small number of large firms taking $81 \%$ of the local market) can make the formation of cartels easier. Since fewer companies have to make agreements to cover the market and it is potentially easier to communicate, coordinate, conceal and monitor the cartel agreements (cf. Jaspers 2017). However, a high number of firms in a market (i.e. low concentration) can make the uncertainties in the market very pressing, increasing the need for anti-competitive agreements (cf. Jamieson 1994). This seems to apply specifically to the situation in the Dutch construction industry.

The main similarities in terms of market conditions and structure are: 1) the big share of public tenders in both industries; 2) frequent use of subcontracting, joint venture and consortium projects in the market, leading to extensive collaboration between firms in the sector; 3) both industries experienced episodes of economic prosperity. In addition, several scholars have looked at the influence of the market structure, formulating certain economic vulnerabilities regarding the involvement of organised crime in legitimate business (Lavezzi, 2008; van de Bunt 2008; Gambetta and Reuter 1995; Reuter 1987). The economy of Sicily is characterised by a large dimension of traditional sectors, such as construction, which also has a strong territorial specificity; a large presence of small firms; a low level of technology; and a large public sector (Lavezzi, 2008). Varese (2011a, b) builds upon the theoretical model of Morselli et al. (2012) to assess local conditions for organized crime to provide services to legitimate business. For instance, locally based competition and low barriers for entry are considered to induce risks for business cartels in construction industry (Varese 2011a, b). These characteristics also apply to both cases in this analysis.

In terms of regulatory changes, both countries have roughly seen an increase in enforcement efforts to tackle several forms of unfair competition, such as bid rigging, price-fixing and market allocation. However, in terms of legislation Canada has had a tradition of criminalisation regarding cartel conduct. While in the Netherlands, there has been a shift away from hardly enforced criminal law towards the use of strongly enforced administrative law. Comparably however, both Canada and the Netherlands experienced a boost in enforcement efforts over the past roughly 25 years, in terms of professionalisation in existing and the formation of new regulatory agencies. Through 
providing competition enforcement with an increase in personnel, resources and investigative powers in order to tackle cartel conduct over the past 25 years.

\section{Results: Bid-rigging in the construction industry in Canada and the Netherlands}

\section{Parliamentary investigations construction industry in Quebec, Canada (1996-2011)}

When the prices of public contracts increased, several whistle-blowers came forward on bid rigging schemes in the province of Quebec, Canada. Upon the initial revelations, the parliamentary commission Charbonneau (CEIC) was installed in 2011. The Commission Charbonneau investigated bid rigging, corruption, illegal financing of political parties and the infiltration of organised crime in the local construction industry in the province of Quebec between 1996 and 2011. During a period of seven months, nearly 50 witnesses testified to the Commission, including entrepreneurs, engineers, technicians, civil servants, political leaders, and the former heads of the city government. The final report was finished in 2015. It covers various forms of misconduct, including corporate crime, corruption and organised crime. Besides bid rigging by construction firms and involvement of organised crime, the Charbonneau investigations cover a great variety of misconduct, such as corruption and illegal financing of political parties. Especially the activities in Laval, Quebec are an example of these types of misconduct (cf. Reeves-Latour and Morselli 2016). However, in light of the research question this article focuses on the Montréal construction cartels.

\section{The Montréal construction cartels}

The Montréal construction cartels involve four bid-rigging schemes regarding public tendering procedures in the engineering and infrastructure sector. The markets include: the construction of aqueducts; construction of sidewalks; construction of city parks; and the construction of roads. The cartel in aqueducts included 15 colluding firms. These firms rotated bids, dividing all local projects in the market. They executed their bid rigging agreement by adjusting their bids, after discussing whose turn it was to win the project. In order to assure this firm would actually win the project the other companies would intentionally turn in higher bids. This is also referred to as 'cover pricing'. The second cartel, in sidewalks, consisted of six firms. A contractor that functioned as a ringleader distributed the available projects by instating fear with competitors, hereby coordinating the cartel. This contractor also tried to organise the construction of city parks (and other markets, such as sewers and aqueducts) using the same strategy, but with limited success. This cartel lasted between two and three years. Since the beginning of the year 2000, the directors of five firms initiated the asphalt cartel. This cartel is considered to be the most professional and structured of the cartels in Montréal. The conspiracy ensured the firms of profits up to $30 \%$, instead of the usual $4-8 \%$. This cartel entailed a market division, using production quotas and allocating the market in the greater city of Montréal. Every plant had a quota based on volumes of production. The cartels also used geographical market allocation, especially in the asphalt plants. By effect, the cartel successfully lowered the level of foreign competition in Montréal. In 2005, public contracts in 
Montréal were awarded to local firms in more than $95 \%$ of the cases. Contractors and entrepreneurs from outside Montréal were bullied and intimidated if they attempted to acquire projects in the Montréal area.

\section{The parliamentary investigations Dutch construction industry (1985-2000)}

In 2001, large-scale bid rigging in the Dutch construction industry was also uncovered by a whistle-blower; the commercial director of a Dutch construction company that was involved in several bid-rigging schemes. As a result, in 2002 The Parliamentary Commission on the Construction industry in the Netherlands (PEB) was appointed to investigate irregularities in the construction industry (PEB 2002). In addition, the Dutch Competition Authority started investigations into several markets within the construction industry, namely the civil engineering and infrastructure sector and the installation sector (NMa 2004). The parliamentary commission investigated what the nature and scale of the irregularities in the Dutch construction industry entailed, from 1985 onwards. Under irregularities they considered: fraud, false reporting, economic crimes, fiscal fraud, public procurement violations and violations of ethical rules within the industry (PEB 2002, p. 31). The Dutch Competition authority investigated infringements of the cartel prohibition under Dutch and European competition law, from 1998 onwards - when the cartel prohibition was first introduced under Dutch administrative law.

\section{The Dutch construction cartels}

The Dutch construction cartels include bid-rigging schemes in public tendering procedures regarding the construction of infrastructure projects in roads, water and groundwork. In each of these markets a group of bidders predetermined the outcome of tendering procedures. Participants took turns winning projects, artificially raising prices and splitting the difference. Firms used a system involving mutual claims to determine whose turn it was to get the next project. In a rigged tendering procedure, the winning firm owed 'credits' to the other participants that let him win the project. Those firms then held 'claims' on the former winner, calculated from the overcharge of the project (the artificially raised amount) divided by the number of participants. These claims were used in future tendering procedures to determine which firm should 'rightfully' win the project. This also enabled firms to come together for any specific project in various compositions and within several markets. In other words, there was no fixed ring of bidders per market or region. Instead, there was a relatively flexible and open system in which every Dutch construction company could participate. Scores of the mutual claims were meticulously kept in general ledgers by all major construction companies. Later on, ironically, these ledgers served as central evidence in the investigations revealing the cartels.

\section{Exclusive versus inclusive: Bid-rigging schemes in public tendering procedures}

Both in the Netherlands and in Montréal, firms in the engineering and infrastructure sector coordinated their bidding process in public tenders. Construction firms 
structurally collaborated in order to determine which firm would be the winner of the contract, using strategies such as cover pricing and courtesy bidding. Moreover, prices of contracts were artificially inflated. Both case studies entail a combination of bid rigging and price-fixing in the construction industry.

\title{
Exclusion: Violence in the Montréal construction cartels
}

Entrepreneurs, especially from the cartels in sidewalk, sewing and aqueducts, were seen at the company of a known leader of the Italian Mafia in Montréal. They regularly frequented the so-called 'social club', which served as a headquarters for the Rizzuto clan. The exchange of money was taped with a hidden camera. According to a witness, the members of the cartel were working 'under the blessing' of the Mafia and paid them compensations, also referred to as 'pizzo'. These forms of taxes or extortion rackets were usually paid to the leader of the cartel in sidewalks. He acted as an intermediary between the cartels and the Mafia. Leaders of the Rizzuto clan acted as mediators to settle conflicts between firms and to prevent newcomers from entering the market.

The cartels operated on a basis of consensus and reciprocity. Contractors made compromises to be able to reach a well-functioning system where all companies involved could benefit. At the same time, the system clearly functioned as a disciplinary instrument for the firms involved. An entrepreneur that participated in one of the cartels explained:

\begin{abstract}
"The interest of entrepreneurs is that the system works, so it was in the interest of everyone involved to push in the same direction, like a hockey team. Once the decision has been made, it must be respected: "If, with every contract, we argued, well, I'll tell you, it would not have lasted more than two weeks. There is no one in charge: decisions are taken by consensus" (CEIC, Tome 2, p. 33).
\end{abstract}

Contrary to the Dutch bid rigging scheme, there was no formal accounting or keeping scores in the Montréal cartel cases. No notebooks or other forms of registration containing names of the companies that won the contracts in Montréal. Comparable to the Dutch cases, the Montréal cartels were based on informal social control between the construction firms in the cartel:

"When I say "keep an eye out", I mean we talked among entrepreneurs, OK, he got this, it is possible that he is at this level, soon ... When there are three contracts in tender, normally it should go to me, him or such. So it was really an exchange amongst the entrepreneurs in the market" (CEIC, Tome 2, p. 31)

Another contractor confirmed that the entrepreneurs were trying to get along with each other in a harmonious way, in order to ensure the rotation of contracts:

"What I am saying is if Infrabec comes to see me and I don't agree, maybe Paul will call me and say: Why aren't you just settling it? You'll get another one that's coming to you, you know" (CEIC, Tome 2, p. 33). 
One of the entrepreneurs, Lino Zambito, declared how 2,5\% of the profits of the cartel were transferred to members of the Cosa Nostra. He added that the system had been in place for many years and was initiated by the construction firms. The involvement of organised criminal groups only started afterwards. He describes a system of kickbacks for services and products that were never actually delivered. This was used to even out disparities between the construction companies and to make cash payments to criminal groups and local politicians (CEIC 2015, p. 239). What Zambito describes can be categorized as a symbiotic relationship between construction firms and criminal groups (Passas 2002; Van de Bunt, Siegel and Zaitch 2014). However, it remains unclear from the data whether this should be seen as collaboration or co-optation (cf. Passas 2002).

One of the standout differences between the Dutch and the Canadian cartels is that in Montréal, construction firms outside the cartel were victimised by members inside the cartel. Firms outside the cartel that wanted to participate in the local construction market in Montréal were bullied, threatened and intimidated into not entering the market or exiting it. Some construction firms in the Montréal area experienced the strong position of the existing cartel through activities of organised criminals. This is demonstrated in the testimonies of several entrepreneurs outside of the bid rigging cartels. They were threatened and bullied by the members of the Cosa Nostra. After acquiring a large new construction project, Martin Carrier -an entrepreneur from the Montréal area- received a call from a director of one of the other construction companies in Montréal, Francesco Bruno. Bruno had also bid on the project and expressed his dissatisfaction about the fact that Carrier was operating in 'his' area and requested that he would stop his activities. Carrier ignored the message and was then phoned again, this time by Del Balso (member of the Rizzuto family, part of the Canadian Cosa Nostra), which told him the following: "You did not want to listen. You were warned. Now it ends". There were no physical repercussions for Carrier, but he was uncomfortable with the situation. In February 2001, professional conflicts between the firms were still on-going in a civil suit. Around that time Carrier received some remarkable mail to his address. It contained a condolences card with his name on it stating: "Dear friend, if you don't stop bidding in Montréal, this is the type of card we will be sending to your family" (CEIC 2015, p. 987).

Another local entrepreneur, Andre Durocher, also declared receiving threats after putting in his price for a project on the 'Chabanel Street' in Montréal. The reason was that he was bidding on projects that were indented to go to members of the cartel. His installations and tools were destroyed and his brother was beaten up. Afterwards, four men visited his office and demanded that he would cancel the project. He ignored their demands. Shortly after, he received a call from the insurance company telling him that the insurance on his equipment was cancelled if he would not retract his bid on the Chabanel Street project. This time Durocher caved in and retracted his bid.

\section{Inclusion: Mutual claims and clandestine bookkeeping}

Firms in the engineering sector in the Netherlands coordinated their bidding in a meeting before the tendering procedure started. One of the Dutch companies explained the aim of these meetings, summarising the main strategy applied within the market to divide public tenders: 
"In a pre-consultation meeting the goal was to determine i) which of the involved firms would execute the project (named 'rightful owner'), ii) for which amount the project would be executed, and iii) which mutual claims between the participating firms would be created as a result of this agreement. The 'price' that the 'rightful owner' would pay to the others, to be the lowest bidder in the tendering procedure, would determine the amount of the claims others would have on him in future tenders" (NMa 2004, p. 7).

The bidding procedure was particularly predictable, because the lowest bidder would always get the tender. In some cases, tenders would not be open to all construction companies but issued by invitation only. One of the companies explained: "In case of tenders by invitation, we would quickly determine which other firms got an invitation to bid on the project" (NMa 2004, p. 9). This also meant the circle of bidders could differ from one project to another. However, the different agreements were strongly related. Although the circle of bidders per tender would differ, there was a structural system in place in which virtually every Dutch construction company participated. A statement of one of the companies involved illustrates the common practice of these activities: "It was custom for all contractors operating in the Dutch market to comply with the system. In fact, there was somewhat of a 'code of honour'" (NMa 2004, p. 13). According to the investigations and testimonies, around $98 \%$ of Dutch construction companies were involved in rigging public tendering procedures. Indeed, the activities entailed a long-standing tradition in the sector, which was passed on to newcomers: "People that were new to the industry were informed and instructed by their predecessor" (NMa 2004, p. 14). Testimonies demonstrate a web of different schemes throughout the industry, making it nearly impossible not to participate in bid rigging agreements if you wanted to be in business. The inevitability of these practices was especially induced by the system of mutual 'claims' that resulted from the preconsultation meetings. One of the companies explained:

"In this pre-consultation, which usually took place 1 or 2 hours before the bidding process, the bidding would be coordinated between the participating firms (...) In addition to the price, the amount for the claims was determined. These claims were then settled and evened out with previous and future projects" (NMa 2004, p. 8).

The coordination and allocation of projects took place through a system of mutual 'rights' and 'obligations', so-called claims. At the pre-consultation meeting, the firms will first write down an amount for which they can potentially execute the project. Firm A writes down the lowest amount, the other firms will now agree that firm A will win the project. Together they will determine for which price firm A will actually submit his bid to get the project. They inflate the earlier amount, which was a competitive price. All other firms will submit a bid above A deliberately, not winning the project as a result. In return, the winner of the project (firm A) will have a 'debt' to the others, based on the difference between the initial amount and the real price of the bid he turns in, divided by the number of participating firms. For example, if the initial amount was 4.75 million and the winner turns in his bid at 4.95 million, the difference of 200.000 
Euros is divided between the other four companies, making the debt of firm A to the others 50.000 Euros per firm (PEB 2002, p. 88).

Because of the accumulation of mutual claims, the participating firms created a web of mutual dependencies. Their relationship with other firms became one of creditors and debtors. It was clear that previously built up claims would play a role in future contracts (NMa 2004, p. 10-11). One of the companies explained:

"It was custom that claims were never intended to be actually paid out in practice. Firms would strive to even out disparities by balancing the claims. In fact, the claims served as 'change' (small cash) for other projects in which a firm would participate. Built up claims were used to acquire projects in other tenders. As a consequence of this system, some firms would only participate in preconsultation meetings, to collect these 'claims'" (NMa 2004, p. 11).

The claims were noted in the general ledger. This way, the claims would materialise and could be used in the future to determine whose turn it was to get a project. The principle of these claims was work in exchange for work" (NMa 2004, p. 23).

As demonstrated above, firms would keep clandestine administrations on agreements and mutual claims; this illustrates the structural character of the system. These administrations had the form of general ledgers. For every company one made agreements with and had a relationship of dependency through mutual claims, several pages were listed. This resulted in a norm of 'fair sharing' between construction companies (van de Bunt 2010; van de Bunt 2008). Besides meticulously kept so-called 'shadow bookkeeping', this social norm was induced by an informal business culture in which people were well acquainted with one another, both professionally and personally. Every company involved in these agreements would keep such an administration. All projects were listed in this administration: companies would note which firm got the project, for which price and the amount of the claims to the other participants. However, it was not always possible to perfectly even out the disparities between the participating firms. As a last resort, firms would therefore sometimes use false invoices for services or products that were never actually delivered. Or they would give large discounts on a shipment of e.g. gravel or other products (PEB 2002, p. 126).

\section{Conclusion}

The purpose of this article was to investigate why business cartels sometimes $d o$ and sometimes do not include the involvement of criminal groups with a violent reputation. The often-separated criminological discourses of organised and organisational crime literature have both treated the phenomenon of economic cartels, respectively framing it as organised crime 'infiltration' and pure corporate conspiracy. However, contemporary studies in organised crime offer extensive elaborations about the interactions and interfaces between 'upper' and 'underworld'. This article has therefore, in the tradition of analysing serious crimes for gain, moved beyond analytical debates and focused on 
the modus operandi, networks and different actors involved in economic cartels. By looking at two different case studies we can see how two different types of collusion emerge under different cultural, economic and regulatory conditions.

Case studies from the construction industry in Canada and the Netherlands demonstrate how two different systems of collusion developed under different regulatory and cultural conditions. The Montréal cartels were a form of exclusive collusion; closed circles of fixed bidders, and construction firms outside the cartel were victimised. The construction cartels in the Netherlands were a form of inclusive collusion; open to all construction firms, with changing compositions. The Montréal cartels were more closed to new entrants, while the Dutch cases demonstrated a collective business strategy. This strategy was shared within the broader industry. This has to do with the history of the construction industry in the Netherlands, in which the combination of enforcement tolerance and the structural character of the way of working were considered 'business as usual'. Additionally, the Dutch construction industry barely had losing or victimised firms as a result of the bid rigging cartels.

Differences regarding involvement of violent criminal groups in business cartels between The Netherlands and Canada can be explained by the cultural and regulatory conditions under which the two cases emerged. Both a strictly criminalised regulatory regime regarding business cartels and a highly competitive and predictable tendering procedure with criminal opportunities in Canada, explain the involvement of criminal groups with a violent reputation. In the Netherlands, the combination of a historically lenient regulatory regime towards business cartels and a strong subcultural normalisation of bid rigging throughout the construction industry explain the emergence of business cartels without the involvement of organised crime.

Relating to the research question, if the system of collusion is more closed and dependent on keeping outsiders out (preventing newcomers from entering the market) and protecting insiders within the cartel, a demand for intimidation is more pressing. This fits the job description of organised criminal groups with a violent reputation. Note that this neither means they have 'infiltrated' the industry completely, nor that they have initiated or forced their services upon the firms involved in illegal bid rigging agreements in the construction industry. This was demonstrated in the Montréal cases that illustrated a symbiotic relationship between criminal groups and collusive business owners (cf. Gambetta and Reuter 1995; Passas 2002; van de Bunt et al. 2014). In the Dutch inclusive system, there is less of a natural need for a strong arm to enforce the existing power balance of construction firms in the industry. Old industry directors informally coordinated cartels, or third parties like secretaries and chairmen functioned sufficiently as regulators or mediators for the cartels (cf. Van de Bunt 2010; Jaspers 2017; Hertogh 2010).

In both cases authors have suggested that it was not failing regulations and regulators, or the strategic creation of an external criminal group that sufficiently explains the misconduct in the construction industry. In fact, it was the vulnerable system itself that produced the misconduct: "What this means is that the collusion problem and the emergence of an organized and centralized group of profiteers is a product of the system itself and not, as popular opinion often suggests, the strategic creation of an external criminal group that arrives to take control of the process at any given time. In short, a vulnerable system begets its own deviant organization and does not require a mafia or organized crime presence to organize it" (Morselli et al. 2012, p. 2). For the Dutch case, several authors have similarly suggested how the structure and culture of the industry and 
its vulnerabilities contributed to the bid rigging schemes, and not as is often suggested regulatory failure alone (Van de Bunt 2008; Van den Heuvel 2005; Vulperhorst 2005). However, although collusion between firms was the main focus of this article, both the Montréal and the Dutch case also revealed collusion between construction firms and governmental agencies, both local and federal (cf. Reeves-Latour and Morselli 2016; Van den Heuvel 2005). The role of the state when it comes to collusion in the construction industry cannot to be underestimated. In a sector where financial and economic interests of the state are so strongly connected to corporate interests and where governments can be client, project developer and regulator at the same time, collusion between government and construction firms is a significant risk.

Acknowledgements The author thanks Henk van de Bunt, Judith van Erp, Nicholas Lord and the anonymous reviewers for their comments on an earlier version of this article.

Funding This study was funded by the Netherlands Organization for Scientific Research (grant number 406-14-027).

\section{Compliance with ethical standards}

Human and animal studies This article does not contain any studies with human participants or animals performed by any of the authors.

Conflict of interest Author J. D. Jaspers declares that he has no conflict of interest.

Open Access This article is distributed under the terms of the Creative Commons Attribution 4.0 International License (http://creativecommons.org/licenses/by/4.0/), which permits unrestricted use, distribution, and reproduction in any medium, provided you give appropriate credit to the original author(s) and the source, provide a link to the Creative Commons license, and indicate if changes were made.

\section{References}

Agnew R, Piquero NL, Cullen FT (2009) General strain theory and white-collar crime. In: The criminology of white-collar crime. Springer, New York, pp 35-60

Anckar C (2008) On the applicability of the most similar systems design and the most different systems design in comparative research. Int J Soc Res Methodol 11(5):389-401

Anechiarico F (1991) Beyond bribery: the political influence of organized crime in new York City. In: Fijnaut CJCF, Jacobs JB (eds) Organized crime and its containment: a transatlantic initiative. Deventer, Kluwer Law, pp 87-100

Ayres I (1987) How Cartels punish: a structural theory of self-enforcing collusion. Columbia Law Rev 87(2): 295

Baker WE, Faulkner RR (1993) The social organization of conspiracy: illegal networks in the heavy electrical equipment industry. Am Sociol Rev:837-860

Bhaskarabhatla A, Chatterjee C, Karreman B (2016) Hit where it hurts: cartel policing using targeted sales and supply embargoes. J Law Econ 59(4):805-846

Boscariol JW, Walker S, Katz M, Kearney E, Dinning J, Sosnow C, Narayanan P, Peaker D, Stras MB, Karas SR, Roberts JC (2010) Canada. The International Lawyer: 613-629

Braithwaite J (1984) Corporate crime in the pharmaceutical industry. Routledge \& Kegan Paul, London

Braithwaite, J. (1989). Crime, shame and reintegration. Cambridge University Press

Campana P, Varese F (2013) Cooperation in criminal organizations: kinship and violence as credible commitments. Ration Soc 25(3):263-289

Chu, Y. K. (2002). The triads as business. Routledge 
Clinard, M., \& Yeager, P. (1980). Corporate crime: the first comprehensive account of illegal practices among America's top corporations

Commission of inquiry on the Awarding and Management of Public Contracts in the Construction Industry (CEIC) (2015) Rapport final. Available from: https://www.ceic.gouv.qc.ca/fileadmin/Fichiers client/fichiers/Rapport_final/Rapport_final_CEIC_Integral_c.pdf. Accessed 06-03-2017

Connor, J. M. (2010). Recidivism revealed: private international cartels 1991-2009. Available at SSRN 1688508

de Bree R (2006) Mededingingsrecht en strafrecht: hernieuwde kennismaking. Markt \& Mededinging 10(7):1

de Jong HW (1990) Nederland: het kartelparadijs van Europa? Economisch-Statistische Berichten 75:244-248

Della Porta D, Vannucci A (1999) Corrupt exchanges: actors, resources, and mechanisms of political corruption. Aldine Transaction, New York

Della Porta, D., \& Vannucci, A. (2012). The hidden order of corruption: an institutional approach. Ashgate Publishing, Ltd.

Dohmen, J., \& Verlaan, J. (2004). De bouwbeerput. Prometheus

Dorn N (2009) The end of organised crime in the European Union. Crime Law Soc Chang 51(2):283-295

Edwards A, Levi M (2008) Researching the organization of serious crimes. Criminol Crim Just 8(4):363-388

Faulkner RR, Cheney ER, Fisher GA, Baker WE (2003) Crime by committee: conspirators and company men in the illegal electrical industry cartel, 1954-19591. Criminology 41(2):511-554

Fijnaut, C. (Ed.). (1998). Organized crime in the Netherlands. Martinus Nijhoff publishers

Franchetti, L. (1876) (1974). Condizioni politiche ed amministrative della Sicilia. Vol. 1 in L. Franchetti and S. Sonnino. Inchiesta in Sicilia

Gambetta, D. (1993). The Sicilian mafia. The business of private protection. Harvard

Gambetta, D., \& Reuter, P. (1995). Conspiracy among the many: the mafia in legitimate industries. The economics of organised crime, 116-36

Geis, G. (1987). White collar crime: the heavy electrical equipment antitrust cases of 1961. In M. D. Ermann \& R. J. Lundmann (Eds.), Corporate and governmental deviance: problems of organizational behavior in contemporary society (pp. 111-130). New York: Oxford University Press

Harding, C., \& Joshua, J. (2010). Regulating cartels in Europe. New York: Oxford University Press

Hertogh MLM (2010) Crime and custom in the Dutch construction industry. Legisprudence 4(3):307-326

Hill, P. (2014). The Japanese Yakuza. In: L. Paoli (red.), The Oxford Handbook of Organized Crime. Oxford: OUP, p. 234-253

Hudon PA, Garzón C (2016) Corruption in public procurement: entrepreneurial coalition building. Crime Law Soc Chang 66(3):291-311

Jacobs JB (1991) Organized crime in the NYC construction industry. In: Fijnaut CJCF, Jacobs JB (eds) Organized crime and its containment: a transatlantic initiative. Deventer, Kluwer Law, pp 49-54

Jacobs, J. B., Friel, C., \& Raddick, R. (1999). Gotham unbound: how New York city was liberated from the grip of organized crime. NYU Press

Jamieson K (1994) The Organization of Corporate Crime: dynamics of antitrust violation. Sage, London

Jaspers JD (2017) Managing cartels: how cartel participants create stability in the absence of law. Eur J Criminal Pol Res 23(3):319-335. https://doi.org/10.1007/s10610-016-9329-7

Kleemans, E. R. (2014). Theoretical perspectives on organized crime. p. 32-52

Kleemans ER, Van De Bunt HG (1999) The social embeddedness of organized crime. Transnational Organized Crime 5(1):19-36

Kleemans, E. \& Van de Bunt, H. G. (2003). The social organisation of human trafficking. In Global organized crime (pp. 97-104). Springer Netherlands

Lavezzi, A. M. (2008). Economic structure and vulnerability to organised crime: Evidence from Sicily. Global crime, 9(3):198-220

Levenstein, M. C., \& Suslow, V. Y. (2006). What determines cartel success? Journal of Economic Literature, XLIV, 43-95

Lippens R, Ponsaers P (2006) Re-visiting the informal economy: introductory notes. Crime Law Soc Chang 45(4-5):259-261

Lord, N., Flores Elizondo, C. J., \& Spencer, J. (2017). The dynamics of food fraud: the interactions between criminal opportunity and market (dys) functionality in legitimate business. Criminol Crim Just, 1748895816684539

Mass R (1991) Law enforcement approaches to organized crime infiltration of legitimate industry. In: Fijnaut CJCF, Jacobs JB (eds) Organized crime and its containment: a transatlantic initiative. Deventer, Kluwer Law, pp 37-47 
Morselli, C., Laferrière, D. \& Reeves-Latour, M. (2012). International experiences in collusion and corruption in the construction industry, Commission d'enquête sur l'octroi et la gestion des contrats publics dans l'industrie de la construction

NMa (2004). Rapport GWW activiteiten. Geraadpleegd via: https://www.acm.nl/nl/publicaties/zoeken-inpublicaties/?zf]]=kw\%3A62\&zf[]=pe\%3Acustom\%7C2004-01-01\%7C2004-12-31\&zf[]=qu\%3AGWW

Paoli L (2002) The paradoxes of organized crime. Crime Law Soc Chang 37:51-97

Paoli (2003) Mafia brotherhood. Organized crime, Italian style. Oxford University Press, New York

Parker C (2013) The war on cartels and the social meaning of deterrence. Regul Gov 7(2):174-194

Passas N (2002) Cross-border crime and the Interface between legal and illegal actors. In: van Duyne PC, von Lampe K, Passas N (eds) Upperworld and underworld in cross-border crime. Wolf Legal Publishers, Nijmegen, pp 11-41

Parlementaire Enquêtecommissie Bouwnijverheid (PEB) (2002) De bouw uit de schaduw. Eindrapport parlementaire enquêtecommissie bouwnijverheid. Sdu Uitgevers, Den Haag

Parlementaire Enquêtecommissie Bouwnijverheid (PEB) (2003) Verhoren 1 t/m 67. Sdu Uitgevers, Den Haag

Petit, L.T.D. (2017, December 8). Legal cartels. Erasmus University Rotterdam. Retrieved from hdl.handle.net/1765/102979

Piquero NL (2012) The only thing we have to fear is fear itself: investigating the relationship between fear of falling and white-collar crime. Crime Delinq 58(3):362-379

Reeves-Latour, M., \& Morselli, C. (2016). Bid rigging networks and state-corporate crime in the construction industry. Soc Networks

Reeves-Latour, M., \& Morselli, C. (2017). Fighting corruption in a time of crisis: lessons from a radical regulatory shift experience. Crime, Law and Social Change, 1-22

Reuter P (1983) Disorganized crime. The economics of the visible hand. The MIT Press, Cambridge

Reuter, P. (1985). Racketeers as cartel organizers. The politics and economics of organized crime, 49-65

Reuter, P. (1987). Racketeering in legitimate industries. A Study in the Economics of Intimidation. Santa Monica: The RAND Corporation

Ruggiero, V. (1996). Organized and corporate crime in Europe: offers that can't be refused. Dartmouth

Ruggiero V (1997) Criminals and service providers: Cross-national dirty economies. Crime Law Soc Chang 28(1):27-38

Shapiro SP (1984) Wayward capitalists. Yale University Press, New Haven

Shortland A, Varese F (2014) The Protector's choice. An application of protection theory to Somali piracy. British Journal of Criminology. In: azu046

Sonnenfeld J, Lawrence PR (1978) Why do companies succumb to price fixing? Harv Bus Rev 56(4):145-157

Stephan A (2010) Cartel laws undermined: corruption, social norms, and collectivist business cultures. J Law Soc 37(2):345-367

Sutherland E (1949) White collar crime. The Dryden Press, New York

van de Bunt HG (2008) Rekeningen vereffenen in de bouw. Tijdschr Criminol 51(2):4

van de Bunt HG (2010) Walls of secrecy and silence. Criminol Public Policy 9(3):435-453

van de Bunt HG, Huisman W (2004) Organisatiecriminaliteit. Tijdschr Criminol 2:106-120

van de Bunt, H.G, Siegel, D., \& Zaitch, D. (2014). The social embeddedness of organized crime. In: L. Paoli (red.), The Oxford Handbook of Organized Crime. Oxford: OUP, p. 321-339

van den Heuvel G (2005) The parliamentary enquiry on fraud in the Dutch construction industry collusion as concept between corruption and state-corporate crime. Crime Law Soc Chang 44:133

van Duyne PC (1995) The phantom and threat of organized crime. Crime Law Soc Chang 24(4):341-377

van Duyne PC (1996) Organized crime, corruption and power. Crime Law Soc Chang 26(3):201-238

van Duyne PC (2007) All in the Dutch construction family: cartel building and organised crime. In: Holmes L (ed) Terrorism, organised crime and corruption: networks and linkages. Edward Elgar, Cheltenham

van Duyne, P. C., von Lampe, K., \& Passas, N. (Eds.). (2002). Upperworld and underworld in cross-border crime. Wolf Legal Publishers

Varese, F. (2011a). Mafias on the move: how organized crime conquers new territories. Princeton University Press

Varese F (2011b) Mafia movements: a framework for understanding the mobility of mafia groups. Global Crime 12(3):281-231

Varese, F. (2014). Protection and extortion. In: L. Paoli (red.), The Oxford Handbook of Organized Crime. Oxford: OUP, p. 343-358

Vulperhorst L (2005) Verzwegen onderneming. Ondernemers, overheid en het einde van het bouwkartel (2001-2005). Uitgeverij Van Gennep, Amsterdam 